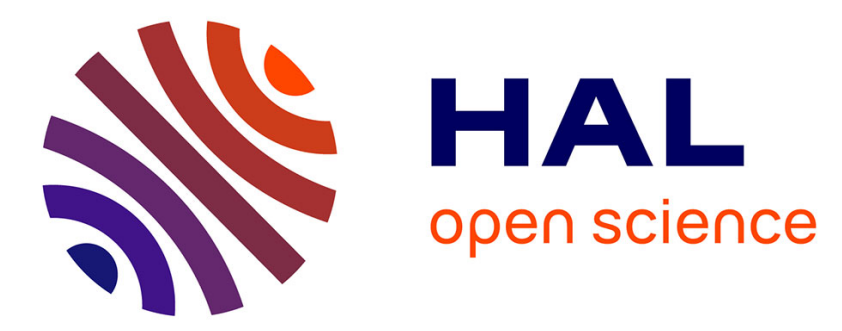

\title{
Trace metals dynamics in surface sediments investigated by DGT micro-scale measurements
}

\author{
Mikael Motelica-Heino, W Davison
}

\section{To cite this version:}

Mikael Motelica-Heino, W Davison. Trace metals dynamics in surface sediments investigated by DGT micro-scale measurements. Journal de Physique, 2003, 107, pp.899-902. 10.1051/jp4:20030443 . hal01335200

\section{HAL Id: hal-01335200 \\ https://hal.science/hal-01335200}

Submitted on 23 Jun 2016

HAL is a multi-disciplinary open access archive for the deposit and dissemination of scientific research documents, whether they are published or not. The documents may come from teaching and research institutions in France or abroad, or from public or private research centers.
L'archive ouverte pluridisciplinaire HAL, est destinée au dépôt et à la diffusion de documents scientifiques de niveau recherche, publiés ou non, émanant des établissements d'enseignement et de recherche français ou étrangers, des laboratoires publics ou privés.

\section{(1) (1) $\$$}

Distributed under a Creative Commons Attribution - NonCommercial - NoDerivatives| 4.0 


\title{
Trace Metals Dynamics in Surface Sediments investigated by DGT Micro-scale Measurements
}

\author{
Mikael Motelica-Heino (1) and William Davison (2) \\ (1) BRGM, 3 Av. Claude Guillemin - F45060 Orléans Cedex 02, FRANCE \\ m.motelica@brgm.fr \\ tel. 0238643886 - fax. 0238643925
}

Institute of Environmental and Natural Sciences, Lancaster University, Lancaster LA1 4YQ

$\mathrm{UK}$

w.davison@lancaster.ac.uk

\begin{abstract}
In surface sediments, metal mobility is controlled by the recruitment and turn-over of organic matter whereas sulphide is thought to control the concentration of metals in sediment pore water by removing them from the solution. DGT is a dynamic probe that measures the kinetically available fraction of metals or sulphide. DGT uses a credit card size probe inserted into the sediment that provides a snapshot of the metal distribution in the sediment, which can be uncovered by spectrochemical analytical techniques. In-situ vertical profiles and horizontal maps of trace metals at high ( $\mathrm{mm}$ scale) and ultra-high resolution $(100 \mu \mathrm{m})$ together with $\mathrm{Fe}, \mathrm{Mn}$ and sulphide were generated from DGT probes deployed in surface sediments. Collectively, the results showed that besides vertical gradients, associated with the depletion of oxygen with depth and the degradation of organic matter by a succession of electron acceptors, small scale remobilisation of metals associated with sediment heterogeneity take place.
\end{abstract}

\section{INTRODUCTION}

The sediment-water interface is chemically and microbially the most active site in natural waters, with steep gradients in physical, chemical and biological properties. Biogenic, authigenic and mineral particles which settle at the sediment surface accumulate to relatively high concentrations and, compared to their time in the water column, have a long residence time in which to react. The microbially mediated oxidation of natural organic carbon and the subsequent reduction of electron acceptors such as $\mathrm{O}_{2}, \mathrm{NO}_{3}{ }^{-}, \mathrm{Mn}(\mathrm{IV}), \mathrm{Fe}(\mathrm{III})$ and $\mathrm{SO}_{4}{ }^{2-}$ results in sharp gradients of $\mathrm{pH}$, redox potential and ionic composition across the interface. The zonations can occur on a very small scale, as shown by measurements of $\mathrm{O}_{2}, \mathrm{pH}$, nutrients and major components with microelectrodes.

Trace metals may be liberated directly from the decomposing organic material or from associated reactions such as the reduction of oxyhydroxides, whereas variation in the concentration of sulfide with sediment depth controls the dissolved concentration of trace metal in sediment pore waters. Metal mobility in sediments is controlled by chemical interactions - redox reactions, (de)sorption and solubility- that take place at the interface between solid phases (minerals/biota) and solution that may occur on a highly localised scale. Any measurements designed to unravel the mechanisms responsible for the local sources of metals must be made not only at a similar fine spatial scale, but also at exactly the same location as the metal 
measurements. Thus high spatial resolution measurement of trace metals remobilization in sediments provides new insight into the biogeochemical processes occurring in surface sediments.

\section{MATERIALS AND METHODS}

The aims of this study were to investigate: (1) the remobilisation of trace metals from lacustrine surface sediments at high ( $\mathrm{mm}$-scale) and ultra-high (sub-mm scale) resolution, (2) the microscale distribution of metals in sediments and their horizontal heterogeneity by measuring in-situ high resolution vertical profiles of trace metals at the sediment-water interface of lakes and provide 2-D maps of metal remobilization together with major dissolved phases.

The novel technique of diffusive gradients in thin-films (DGT) uses a credit card size probe inserted into the sediment, minimum disturbance of the sampled medium. Metal ions bind to a chelating resin after diffusion through a layer of polyacrylamide hydrogel [1]. Measurement of the accumulated mass of metal in the resin-gel enables calculation of the concentration in the pore waters at the probe's surface. This reflects the bulk pore water concentration and the supply from solid phase to solution, as shown by numerical modelling of the DGT-sediment system [2]. Sharp features that have been observed in DGT profiles therefore reflect local mobilisation of metals. Similarly, DGT with AgI gels can be used for the measurement of dissolved sulfide : sulfide species from the sampled waters diffuse through the diffusive gel react with $\mathrm{AgI}$ to form $\mathrm{Ag}_{2} \mathrm{~S}$ [3]. In this study, several DGT system were used for simultaneous measurements of pore water interfacial concentrations of Fe, Mn and S(-II) at exactly the same location in sediments.

Bulk and gross (mm scale) measurements of the DGT probes can be carried out after slicing and back elution of the gels using conventional chemical solution analysis. Alternatively, beam techniques can be used for the direct micro and profile analysis of the DGT devices to generate high spatially resolved profiles of trace metals [4] and mapping of the sulfide distribution can be performed by densitometry analysis.

DGT devices were deployed in anoxic lacustrine and estuarine sediments. In-situ analysis of the gels was then performed by Laser ablation Inductively Coupled Plasma Mass Spectrometry (LA-ICP-MS) to determine in-situ ultra-high resolution (100 $\mu \mathrm{m})$ vertical profiles at the sediment-water interface and horizontal profiles of trace metals.

\section{RESULTS AND DISCUSSION}

Multi-elementary profiles for trace metals together with Fe, Mn and S(-II) could then be established and used to provide mechanistic information about the remobilization processes of metals at the water-sediment interface. For instance, figure 1 shows a typical Mn profile measured by DGT at the sediment water interface at a resolution of $2 \mathrm{~mm}$. Collectively, results revealed trace metals depth profiles that can be related to the major geochemical processes with additional fine scale features, suggesting a highly heterogeneous distribution of metal sources in sediments, superimposed on regular vertical changes. For instance, remobilisation profiles in sediment show a correlation between $\mathrm{Zn}, \mathrm{Ni}$ and $\mathrm{Cu}$ on one hand, and between $\mathrm{Co}$ and $\mathrm{Mn}$ on the other hand, suggesting distinct remobilisation processes, respectively the decomposition of organic material and a redox response.

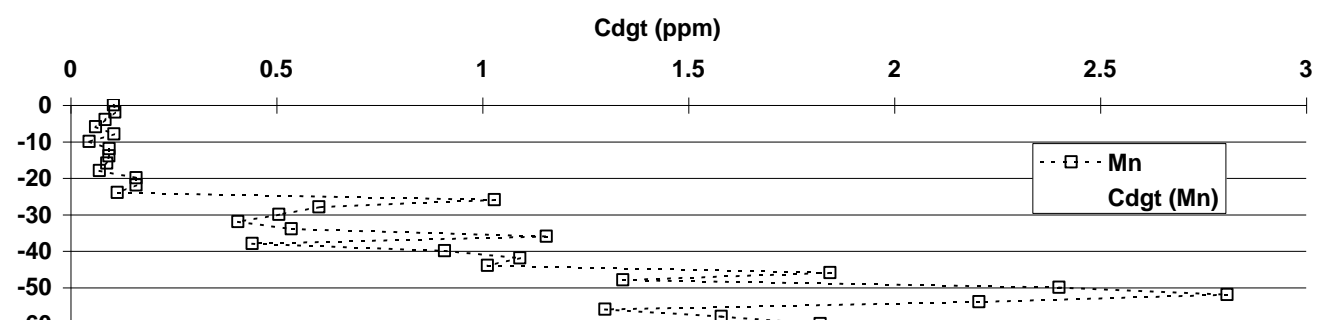


Figure 1. Remobilisation profile for $\mathrm{Mn}$ at the sediment-water interface (Esthwaite Water, Cumbria, UK).

Furthermore, two-dimensional images of the sulfide and metal distribution revealed highly localised sources or sinks of metals in the sediment. Figure 2 shows a typical densitometric image of dissolved sulphide distribution in an anoxic sediment, with the e occurrence of local sources of sulphide, that also correspond to the remobilisation of $\mathrm{Fe}$ and trace metals.

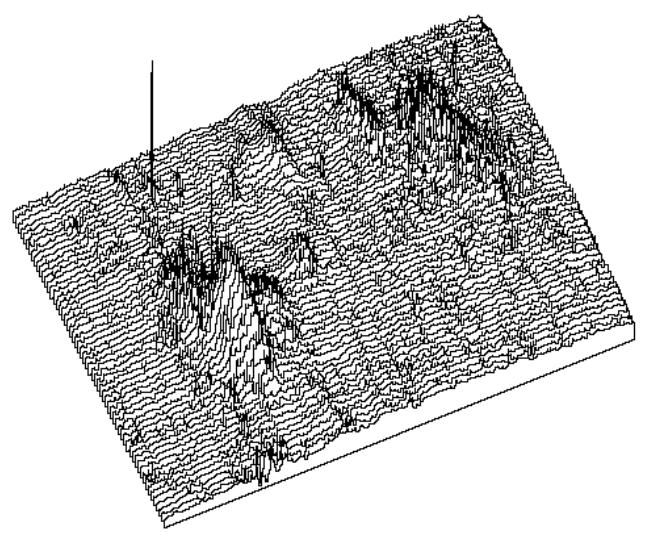

Figure 2. Remobilisation of dissolved sulphur measured by DGT $(1 \times 1.5 \mathrm{~cm})$ profile for $\mathrm{Mn}$ in Esthwaite Water sediment.

The results show the correspondence between fine structure observed for the different trace metals and fine structure in sulfide, iron and manganese is providing insight into the linkages of the supply/removal processes of metals at a small scale, particularly the role of $\mathrm{Fe}, \mathrm{Mn}$ and $\mathrm{S}(-\mathrm{II})$ phases and microorganisms. This work is contributing to the emergence of a new paradigm for the behaviour of metals in sediments. Small-scale remobilisation within a 3-dimensional framework (microniches) appears to be superimposed on the relatively macro features of systematic vertical changes associated with redox zones. Oxygen consumption and production may occur within adjacent microzones only 100 microns apart [5]. The transformation of elements within sediments from one chemical form to another (solid phase/solution, redox 
state) may also occurs locally at the cluster of mineral or organic particles involved must actually be understood at the level of individual particles.

Candidates for the origins of the metal microniches include: a) release from decomposing organic material translocated by biota; (b) release from oxyhydroxides reduced by electrons supplied by translocated organic material; (c) release from iron and other metal sulfides translocated by biota into more oxidising environments; (d) controlled release by microorganisms, either indirectly (organic decomposition) or directly (metals involved in physiology); (e) release from skeletal material (e.g. silica frustules).

\section{References}

[1] Zhang H. and W. Davison W., Anal. Chem. 67 (1995), 3391-3400.

[2] Harper M., Davison, W., Zhang, H. and Tych, W., Geochim. Cosmochim. Acta., 62 (1998)., 2757-2770.

[3] Teasdale P.R., Hayward S. and W. Davison W., Anal. Chem. 71 (1999), 2186-2191.

[4] Motelica-Heino, M. and W. Davison. 2000. Journal of Conference Abstracts, Goldschmidt Conference, September $3^{\text {rd }}-8^{\text {th }}$ 2000, Oxford, UK, 5, p. 724.

[5] Glud R.N., Gundersen J.K. and Ramsing N.B. in. In situ monitoring of Aquatic Systems (Buffle, J. and Horvai, G., eds.), Wiley, Chicester, 2000) pp.19-75. 